\title{
Susceptibility of larval Crepidula fornicata to predation by suspension- feeding adults
}

\author{
Jan A. Pechenik ${ }^{\mathrm{a}^{*}}$, Michel Blanchard ${ }^{\mathrm{b}}$ and Randi Rotjan ${ }^{\mathrm{a}}$
}

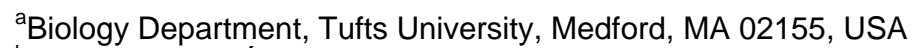 \\ ${ }^{b}$ Departement d'Écologie Côtière, Institut Français de Recherche et d'Exploitation de la Mer, BP 70-Plouzané- \\ 29280, France \\ *: Corresponding author : jan.pechenik@tufts.edu
}

\begin{abstract}
The slipper shell snail Crepidula fornicata forms dense assemblages along much of the European coast, where it co-occurs with oysters. We examined the susceptibility of slipper shell larvae to predation by suspension-feeders, including adults of their own species. In particular, we compared filtration rates on phytoplankton with those on larvae, and determined the extent to which consumption of larvae varied with adult size, larval size, and with the presence of alternative food (phytoplankton). We also examined the ability of competent larvae to metamorphose successfully in the presence of feeding adults. For each experiment, adults were held in plastic jars with seawater or phytoplankton suspension and allowed to graze on larvae (101 larvae per jar) for 4-6 $\mathrm{h}$ at room temperature (21-23 ${ }^{\circ} \mathrm{C}$ ); larvae were kept in circulation with gentle aeration. Adults of $\mathrm{C}$. fornicata ingested substantial numbers of larvae over the complete range of sizes tested, about 450-850 $\mu \mathrm{m}$ shell length. Ingestion rates were reduced by $43-50 \%$ in the presence of phytoplankton, and were not correlated with adult shell length. The rates at which larvae were removed by adult slipper shells were generally lower than predicted from the rates at which the same adults ingested phytoplankton, suggesting either some ability of larvae to avoid capture or some difficulty of adults in consuming larvae entrained into their feeding currents. Slipper shell larvae were also readily consumed by adult oysters (Ostrea edulis and Crassostrea gigas), and indeed oysters consumed larvae at faster rates than predicted from their phytoplankton ingestion rates. Nevertheless, substantial numbers of competent larvae managed to metamorphose successfully during the test periods, either on the sides of the jars they were in or on the adults' shells, suggesting that recruitment probably continues in the field even when suspensionfeeding adults are at high concentrations in the benthos.
\end{abstract}

Keywords: Predation; Susceptibility; Larvae 


\section{Introduction}

The larvae of benthic marine invertebrates must suffer considerable mortality between their release into the plankton and their metamorphosis into the benthos, and a substantial portion of that mortality is probably caused by predators (reviewed by Thorson, 1950; Rumrill, 1990; Morgan, 1995; Pechenik, 1999). Bivalves and other suspension-feeders are likely predators both when larvae are first released into the plankton and later when competent larvae descend to the benthos to explore substrates in preparation for metamorphosis (Thorson, 1950; Woodin, 1976; Cowden et al., 1984; Young and Chia, 1987; Rumrill, 1990; André et al., 1993; Morgan 1992, 1995; Lehane and Davenport, 2002). Blue mussels (Mytilus edulis) and oysters (Crassostrea virginica), in particular, appear to consume and digest large numbers of larvae, including those produced by members of their own and other bivalve species (e.g., Thorson, 1950; Mileikovsky, 1974; Cowden et al., 1984; Tamburri and Zimmer-Faust, 1996; Lehane and Davenport, 2002).

The potential for larviphagy -the cannibalism of larvae by adults (Timko, 1979)--by the suspensionfeeding gastropod Crepidula fornicata has not been previously reported. As with larvae of many other benthic marine invertebrates (e.g., reviewed by Burke, 1986; Pawlik, 1990), the larvae of $C$. fornicata are induced to metamorphose by chemicals released by adults (Pechenik, 1980; McGee and Targett, 1989; Pires et al., 2000); thus they are likely to associate with adults during the period of substrate exploration prior to metamorphosis. Moreover, adults can form dense aggregations (e.g., Chipperfield, 1951; Walne, 1956; Ehrhold et al., 1998; Sauriau et al., 1998; de Montaudouin et al., 1999; Thieltges et al., 2003)( Fig. 1), increasing the likelihood that larvae will be entrained into adult feeding currents; as with bivalves and solitary ascidians (e.g., Thorson, 1950; Willemsen, 1954; Bingham and Walters, 1989), adults of C. fornicata pass substantial quantities of water through their mantle cavities, about $200-400 \mathrm{~mL}$ of water per h (Newell and Kofoed, 1977a, b; Lesser et al., 1992). Although adult Crepidula fornicata are reported to ingest oyster larvae in the field (Korringa, 1951) and adult oysters are known to ingest young larvae of $C$. fornicata in the laboratory (Tamburri and Zimmer-Faust, 1996), there are no comparable data for predation by adults of $C$. fornicata on larvae of their own species.

There are good reasons to expect that adults of $C$. fornicata might not consume their own larvae. First, adults might be able to recognize and reject their own larvae: at least some suspension-feeders can distinguish between their own eggs or larvae (which they do not ingest) and other potential food particles, including the eggs of other species (Young, 1988; Chaparro et al., 1993). Also, the larvae of C. fornicata are quite large, typically 400-450 $\mu \mathrm{m}$ when first released into the plankton (Pechenik, 1980, 1984) and about 800-1200 $\mu \mathrm{m}$ when they first become competent to metamorphose (Pechenik and Heyman, 1987). Indeed, the large size of these larvae at competence could be an adaptation to reducing predation by suspension-feeding adults during the period of substrate exploration. By comparison, bivalve larvae are typically less than $125 \mu \mathrm{m}$ when they first develop shells (e.g., Davis and Ansell, 1962; Davis and Calabarese, 1964; Bayne, 1965; Johnson and Shanks, 2003), and are rarely much larger than about $300 \mu \mathrm{m}$ when ready to metamorphose (e.g., Bayne, 1965; Coon and Bonar, 1986; Pechenik et al., 1990; André et al., 1993; Tamburri and Zimmer-Faust, 1996). 
Fig. 1. Adults of Crepidula fornicata at a depth of $3 \mathrm{~m}$ in the Bay of Cancale, May 2001.

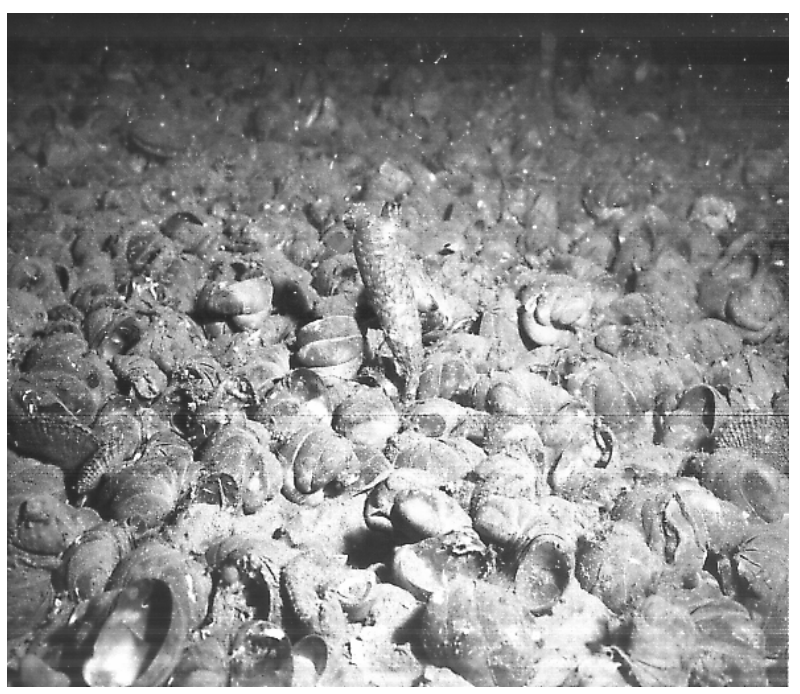


In addition to possibly being protected by adult recognition and their large size, the larvae of $C$. fornicata might avoid predation by Crepidula and other suspension-feeders through behavior. They might, for example, be able to sense and react to feeding currents produced by adults before becoming entrained (e.g., Jakobsen, 2001; Titelman, 2001; Green et al., 2003). This possibility was not examined by Tamburri and Zimmer-Faust (1996), who injected larvae of $C$. fornicata directly into the inhalent stream of oysters. Finally, the larvae might be ingested by adults, but survive passage through the predator's gut and emerge alive (reviewed by Mileikovsky, 1974; Morgan, 1995).

The topic is of interest in part because we currently have a very limited understanding for any benthic marine invertebrate of the amount of mortality that takes place during substrate searching, and of the potential contribution made by conspecific adults to that mortality (reviewed by Rumrill, 1990, and Morgan, 1995). In addition, adults of $C$. fornicata (and many other suspension-feeding molluscs) have generally been viewed as herbivores (Walne, 1956; Bayne, 1976; Newell and Kofoed, 1977a, b; Lesser et al., 1992; Declerck, 1995; Lehane and Davenport, 2002), whereas their ecological role may actually be much broader (Riera et al., 2002).

There are also practical reasons for investigating this issue of larval consumption for C. fornicata. Although native to the east coast of the U.S., C. fornicata has been spread widely over the past 50 years, to the west coast of the U.S., the U.K., Scandinavia (Sjøtun, 1997), and much of Northern Europe (reviewed by Walne, 1956; Blanchard, 1997; Thieltges et al., 2003). In the Bay of Mont-Saint Michel alone (France), individuals of $C$. fornicata cover about $15 \%$ of the total bottom surface area, with as many as 9,000 individuals per $\mathrm{m}^{2}$; the total biomass of $C$. fornicata in the bay exceeds 137,000 tons (Ehrold et al., 1998; Blanchard and Ehrhold, 1999). We wished, therefore, to explore the possibility that predation by adults on larvae might eventually exert a degree of self-control on future population growth. Moreover, as populations of $C$. fornicata commonly co-occur with those of oysters (Korringa, P., 1951; Walne, 1956; Blanchard, 1997; Riera et al., 2002), we also investigated, to a lesser extent, potential predation on the larvae by adults of two oyster species present in the Bay of St. Michel, Crassostrea gigas and Ostrea edulis.

\section{Materials and methods}

\subsection{General approach}

Our studies were conducted in the laboratory of the Musèum National d'Histoire Naturelle in Dinard, France (Brittany) in summer 2001, and at the IFREMER mariculture laboratory in Argenton (Brittany) in summer 2003. Most of the experiments address the degree to which adults of $C$. fornicata consume their own larvae, and the extent to which consumption is affected by adult size, larval size, stage of larval development, and the presence of alternative food (phytoplankton). The goal of each experiment is summarized in Table 1. 
Table 1. Experiments conducted with adults of Crepidula fornicata and their larvae.

\begin{tabular}{|c|c|c|c|c|c|}
\hline Experiment & $\begin{array}{l}\text { Filtration on } \\
\text { phytoplankton }\end{array}$ & $\begin{array}{l}\text { Filtration } \\
\text { on larvae }\end{array}$ & $\begin{array}{l}\text { Filtration on } \\
\text { small vs large larvae }\end{array}$ & $\begin{array}{l}\text { Food vs } \\
\text { no food }\end{array}$ & $\begin{array}{l}\text { Ingestion vs } \\
\text { metamorphosis }\end{array}$ \\
\hline I & $\mathrm{X}$ & $\mathrm{X}$ & & & \\
\hline II & $X$ & $\mathrm{X}$ & & & \\
\hline III & $\mathrm{X}$ & $\mathrm{X}$ & & & \\
\hline IV & & $\mathrm{X}$ & $\mathrm{X}$ & & $\mathrm{X}$ \\
\hline V & & $\mathrm{X}$ & & & $\mathrm{X}$ \\
\hline VI & $\mathrm{X}$ & $\mathrm{X}$ & & & \\
\hline VII & & $\mathrm{X}$ & $\mathrm{X}$ & & \\
\hline VIII & & $\mathrm{X}$ & $\mathrm{X}$ & & \\
\hline IX & & $\mathrm{X}$ & & $\mathrm{X}$ & \\
\hline $\mathrm{X}$ & & $X$ & & $\mathrm{X}$ & \\
\hline XI & & $X$ & & & $\mathrm{X}$ \\
\hline
\end{tabular}

\subsection{Obtaining and maintaining adults and larvae of C. fornicata}

Crepidula fornicata is a protandrous hermaphrodite (Coe, 1936; Hoagland, 1978; Wright, 1988) that forms semi-permanent breeding aggregations (stacks) of males and females (Coe, 1936; Gaffney and McGee, 1992; Collin, 1995). Stacks of adult Crepidula fornicata were dredged from the Bay of Mont St. Michel in northern France (latitude 48 $40^{\prime} \mathrm{N}$, longitude $1^{\circ}$ 50' W) on May 21, 2001 and June 23, 2003, and maintained in the laboratory in flowing seawater (approximately $17^{\circ} \mathrm{C}$ ).

To obtain larvae in 2001, several stacks of adults were brought to room temperature (approximately $21-23^{\circ} \mathrm{C}$ ) under a natural photoperiod ( 16 hours L: 8 hours D) produced by ambient window lighting. In 2003, seawater was passed through a large $200 \mu \mathrm{m}$ mesh filter as it exited the main holding tank, so that larvae were collected automatically as they were released. Within 12 hours of their natural release from females, the larvae were harvested on nitex mesh (approximately $150 \mu \mathrm{m}$ mesh size) and transferred to 1.5 - 2 L of seawater in plastic (2001) or glass (2003) containers, in which they were cultured at room temperature with a natural photoperiod as described above. In 2001, seawater for culturing larvae was sterilized by acidification with $\mathrm{HCl}$ (to a pH of 2-2.5) overnight before use. The $\mathrm{pH}$ was restored to 8.14 the following day using a solution of sodium carbonate and the seawater was then forced through a $1.2 \mu \mathrm{m}$ filter before use in experiments. Acidification of seawater was not required in 2003.

Larvae were maintained at approximately 1 individual $\mathrm{mL}^{-1}$ and fed the naked flagellated protist Isochrysis galbana (clone T-ISO) in log phase growth at approximately $18 \times 10^{4}$ cells $\cdot \mathrm{mL}^{-1}$. Larvae were transferred to new phytoplankton suspension in clean containers every 2 days, and shell lengths were determined at intervals-using a dissecting microscope at $40 \mathrm{X}$ equipped with an ocular micrometer--to monitor larval growth. Experiments were performed with larvae released from 7 different females in 2001 and an unknown number of females in 2003 (at least 6, but there were many dozens of females in the holding tank). 


\subsection{General methods for determining predation and filtration rates}

Predation rates were estimated by the rate at which larvae disappeared from confined volumes of seawater, allowing us to calculate per capitata filtration rates $\left(\mathrm{mL}\right.$ water filtered $\cdot$ individual $^{-1} \cdot \mathrm{h}^{-1}$ ) as discussed below.

To determine the extent to which larvae avoided ingestion, either through escape behavior or rejection by adults, we also determined filtration rates of the same adults feeding on phytoplankton. Similar filtration rates on both food sources would argue against escape or rejection of larvae by adults. Lower filtration rates calculated from the disappearance of larvae would suggest escape-or avoidance of capture-by larvae, or rejection by adults. Higher filtration rates calculated from rates of larval disappearance would indicate preferential ingestion of larvae by adults. We are not aware of any similar design in previous studies with this or other species. Four such experiments were conducted with adults of C. fornicata (36 individuals in total), 2 with European flat oysters, Ostrea edulis (10 animals total, with the same animals used in each experiment, about one week apart), and one with adult Pacific oysters, Crassostrea gigas (8 animals total).

For all experiments, adults were measured to the nearest $0.1 \mathrm{~cm}$ using vernier calipers. Shells were then scraped thoroughly to remove barnacles, polychaetes, and other epifauna. We also determined the wet weight of live animals (including the shell), to the nearest $0.1 \mathrm{~g}$. Plastic jars $(1.5 \mathrm{~L})$ containing about 700 $\mathrm{mL}$ seawater or phytoplankton suspension were used for all feeding studies, with one adult per jar. All seawater used in 2001 experiments was obtained from the running seawater taps of the Dinard laboratory and passed through a paper filter (Whatman filter \#41) before use. For 2003 experiments, seawater was forced through $1 \mu \mathrm{m}$ cartridge filters before use. Water $\mathrm{pH}$ was 8.1-8.2 and the salinity was $34 \mathrm{ppt}$. During experiments, the water in each jar was aerated through a single thin plastic tube (or, in 2003, a tube culminating in a glass Pasteur pipet), with a bubble rate of approximately 5 bubbles/minute to keep larvae well dispersed. All experiments were conducted at room temperature, $21-23^{\circ} \mathrm{C}$.

Experiments using different adults of $C$. fornicata and different batches of larvae are designated by roman numerals. Experiments I-V were conducted in 2001, Experiments VI-XI were conducted in 2003. The three experiments with adult oysters are not designated by number, but in some cases were run simultaneously with those for adult Crepidula using larvae from the same females; all were conducted in 2001.

\subsection{Feeding of adults on phytoplankton}

\subsubsection{Crepidula}

Filtration rates were determined from the rate at which phytoplankton concentrations declined over time in closed containers. Adults were chosen to cover a large range of sizes (1.5-5 cm shell length). To prepare adults for experiments, selected individual adults were separated from their stacks, leaving the shell directly beneath them intact; the animal in the lower shell was then removed, unless the lower shell was already empty. Individuals were then maintained in flowing seawater for 1-3 d prior to use in experiments. Water circulation was maintained by gentle aeration during each experiment, at a rate of about 5 bubbles per second as previously noted.

Experiments were conducted on 7 different dates between May 23 and June 11, 2001. For most experiments, at least 8 adult snails were placed individually in plastic jars with $700 \mathrm{~mL}$ of filtered seawater at an initial phytoplankton (Isochrysis galbana, clone T-ISO, cell size 4-6 $\mu \mathrm{m}$ ) concentration of 18 - $20 \mathrm{X}$ $10^{4}$ cells $\mathrm{mL}^{-1}$. One-mL water samples were taken from 2 control containers (no adults) at $\mathrm{T}_{0}$. One-mL water samples were later taken from each feeding chamber after 1,2 , or $3 \mathrm{~h}$, depending on the rates of phytoplankton consumption determined by noticeable changes in water clarity. The water in each container was thoroughly mixed before samples were withdrawn. Water samples were immediately preserved with 1 drop (approximately $0.05 \mathrm{~mL}$ ) of Lugol's iodine and cell counts were made using a glass hemacytometer. Each cell concentration estimate was based on at least 2 subsamples from each container.

Filtration rates ( $\mathrm{mL}$ water filtered $\mathrm{h}^{-1}$. individual ${ }^{-1}$ ) were calculated by dividing the ingestion rate (cells eaten $\mathrm{h}^{-1}$. individual ${ }^{-1}$ ) by the average phytoplankton concentration (mean cells $\cdot \mathrm{mL}^{-1}$ ) during the feeding period (Marin et al., 1986). 


\subsubsection{Oysters}

Ten adults of Ostrea edulis ranging in total weight between 53.9 and $88.3 \mathrm{~g}$ (6.3- $7.6 \mathrm{~cm}$ shell length) were obtained in 2001 from the Bay of Cancale, France. Five adults of Crassostrea gigas ranging in weight between 32.5 and 137.4g (6.1 - $10 \mathrm{~cm}$ shell length) were obtained from the Bay of Cancale, and 2 more adults, weighing 75.9 and $85.9 \mathrm{~g}$ (8.7 and $9.3 \mathrm{~cm}$ shell length, respectively), were obtained from the IFREMER laboratory in Argenton. Filtration rates were determined by monitoring the disappearance of phytoplankton over 1-3 h periods, as described above.

\subsection{Determining adult predation on precompetent larvae}

Immediately after determining its feeding rate on phytoplankton, each adult was rinsed, returned to its container, and placed in $700 \mathrm{~mL}$ of freshly filtered seawater. One hundred and fifty young larvae (1-3 days old) of $C$. fornicata were removed from a larval culture and 25-30 of these were subsampled to determine mean larval size, measuring them at $40 \mathrm{X}$ using a dissecting microscope fitted with an ocular micrometer. Measured larvae were discarded. 101 larvae from those remaining were added to each jar with an adult and the water was gently aerated as already described. Two jars served as controls, with larvae but no adults. After 5-7 hours (details are presented with the results), adults were removed from the bottles and thoroughly rinsed to dislodge any adhering larvae; the number of larvae still alive in each bottle was then determined. Mean filtration rates were estimated as for phytoplankton, by dividing the ingestion rate (larvae eaten $\mathrm{h}^{-1}$. individual ${ }^{-1}$ ) by the average larval concentration (mean larvae $\cdot \mathrm{mL}^{-1}$ ) during the feeding period. Five such experiments were conducted, all in 2001.

\subsection{Influence of larval size on vulnerability to predation by adults of $C$. fornicata}

Three experiments were conducted with adults of C. fornicata (one in 2001, two in 2003) to determine how larval size influences vulnerability to ingestion by adults. These experiments were conducted in the absence of phytoplankton, to maximize ingestion of larvae. In Experiment IV, adults were first allowed to feed for $6 \mathrm{~h}$ on small larvae (see below, 101 larvae per container), and then allowed to feed for another $6 \mathrm{~h}$ on larger larvae (101 per container). For the other 2 experiments, we added 51 small (recently hatched) larvae and 51 large larvae to each of either 6 (Experiment VII) or 10 containers (Experiments VIII) and allowed adults to feed on larvae of both sizes simultaneously for $4-5 \mathrm{~h}$. We then determined the number of large and small larvae remaining in each container. Details are presented with the data, but the large larvae were on average about $200 \mu \mathrm{m}$ larger than the small larvae. With one exception, no larvae were competent to metamorphose in these experiments, as determined by testing subsamples of larvae with excess $\mathrm{K}+$ (see below). In Experiment IV, about $10 \%$ of larvae were competent to metamorphose [mean $\pm \mathrm{SD}(\mathrm{N})=9.5 \pm 8.3 \%$ (3)]; since only $1.9 \%$ of larvae metamorphosed during the $6 \mathrm{~h}$ study, we used the data from this experiment as a test of size discrimination as well as test of metamorphic capacity in the presence of suspension-feeding adults.

\subsection{Influence of phytoplankton on the consumption of larvae}

These experiments-all conducted in 2003-- were nearly identical with those already described, except that phytoplankton (at about $18 \times 10^{4}$ cells $\mathrm{mL}^{-1}$ ) and larvae (101 per container) were present simultaneously in some treatments.

One experiment was conducted in 2003 to see whether adults of $C$. fornicata would consume their own larvae even in the presence of phytoplankton. Adults were allowed to feed for $5 \mathrm{~h}$ on larvae (101 larvae per container) in the presence of phytoplankton suspension (8 replicates). One-mL seawater samples were taken after $2 \mathrm{~h}$ to determine changes in phytoplankton concentration using an electronic particle counter (Coulter Electronics) and phytoplankton concentrations were restored as necessary to maintain the approximate initial concentration over the next $3 \mathrm{~h}$. The number of larvae remaining in each container was determined after $5 \mathrm{~h}$.

Two additional experiments were designed in 2003 to assess the degree to which the simultaneous presence of phytoplankton altered rates at which larvae were consumed. In each experiment, either 5 or 6 adults were offered only larvae (101 larvae per container) while another 5 or 6 adults were simultaneously offered larvae in the presence of phytoplankton. Again, in the second treatment phytoplankton was added 
periodically as necessary, to maintain high concentrations. The final number of larvae in each container was determined after $4 \mathrm{~h}$.

\subsection{Determining the fate of competent larvae}

Four experiments examining the vulnerability of competent larvae were conducted in 2001, two using adult $C$. fornicata (10 replicates in one experiment, 4 replicates in the other) and two using adults of the oyster Ostrea edulis (5 replicates and 10 replicates, respectively). One additional experiment was conducted with adult $C$. fornicata in 2003 (6 replicates). These experiments were all conducted in the absence of phytoplankton, to maximize filtration rates (see Results). Adults were allowed to graze on larvae and the number of larvae remaining was determined after $6 \mathrm{~h}$. Adult shells and the walls of each container were then carefully inspected for metamorphosed individuals.

Percent competence was assessed by incubating larvae (3 replicates of 12 - 16 larvae each, standardized within each experiment) for $6 \mathrm{~h}$ in $20 \mathrm{mM}$ excess $\mathrm{KCl}$ in seawater (Pechenik and Heyman, 1987; Pechenik and Gee, 1993). The excess $\mathrm{K}^{+}$apparently stimulates metamorphosis through a dopaminergic pathway (Pires et al., 2000; Pechenik et al., 2002), possibly by depleting a natural inhibitor of metamorphosis (Pechenik et al., 2002).

\subsection{Direct observations of larval consumption}

Direct observations of adult slippershell snails feeding on their own larvae were made on 4 occasions in 2001. For the first 3 sets of observations, one adult $(2.9 \mathrm{~cm}$ shell length for the first study, $1.2 \mathrm{~cm}$ for the second study, and $2.3 \mathrm{~cm}$ for the third study) was placed in a glass dish with $75 \mathrm{~mL}$ of seawater, with the water just covering the top of the shell. $12-17$ precompetent larvae were then gently injected by pipet into the incurrent stream on the left side of the shell, one at a time over 15-20 minutes, and their fates were observed while viewing them through a dissecting microscope at $12 \mathrm{X}$ magnification. For the fourth set of observations, 50 larvae were pipetted into the container housing the adult $(2.1 \mathrm{~cm}$ shell length), and we then monitored activity at the anterior area of the adult shell for 20 minutes. The larvae in these observations were $500-550 \mu \mathrm{m}$ in shell length.

\subsection{Data Analysis}

Data were analyzed by linear regression or paired t-tests, as appropriate. Nonparametric statistics were used when variances were not homogeneous.

\section{Results}

\subsection{General}

At least $98 \%$ of larvae were accounted for in all jars at the end of the experiments.

\subsection{Filtration on phytoplankton by adults of $C$. fornicata}

Individual filtration rates at $\sim 21-23{ }^{\circ} \mathrm{C}$ ranged between about 15 and $855 \mathrm{~mL}$ filtered $\mathrm{h}^{-1}$ individual $^{-1}$ (Mean $=225.2 \mathrm{~mL} \mathrm{~h}^{-1}, \mathrm{SD}=178.1, \mathrm{~N}=26$ ), based on rates of phytoplankton disappearance (Fig. 2).

Filtration rates during these 1-3 h experiments did not vary predictably with adult shell length (Fig. 2; $\mathrm{r}^{2}=$ 0.125 ; F test for non-zero slope $=3.48 ; \mathrm{df}=1,24 ; \mathrm{p}=0.08$ ). Phytoplankton concentrations typically declined by $8 \%$ - $76 \%$ in individual jars during the experiments, but almost always remained above $8 \mathrm{X}$ $10^{4}$ cells $\cdot \mathrm{mL}^{-1}$, the approximate critical food concentration for juveniles of this species, above which filtration rates are constant (Eyster and Pechenik, 1988). Phytoplankton concentrations in control containers did not change appreciably during the experiments. 
Fig. 2. Influence of adult shell length on rates of phytoplankton consumption by $C$. fornicata in 1-3 h experiments at $23^{\circ} \mathrm{C}$. Mean larval shell lengths \pm SD (N) were as follows: Exp I: $488.5 \pm 24.1$ (14); Exp II: $516.4 \pm 17.2$ (12); Exp III: $514.6 \pm 29.0$ (12). Mean filtration rate for all data combined: $225.2 \mathrm{~mL}$ filtered $\mathrm{h}^{-1} \pm 178.1(26) . \mathrm{r}^{2}=0.125 ; \mathrm{F}=3.48, \mathrm{df}=1,24 ; \mathrm{p}=0.077$.

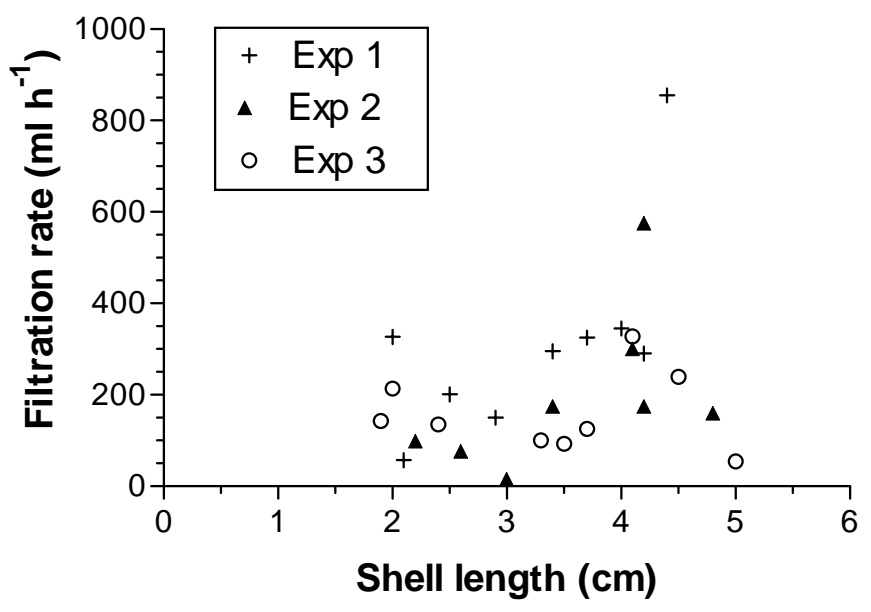




\subsection{Consumption of precompetent larvae by adults}

Adults of $C$. fornicata ingested large numbers of small precompetent larvae in all 5 experiments, with some individuals consuming $100 \%$ of the larvae offered during the $6 \mathrm{~h}$ experiments (mean consumption $=$ $50.5 \%$ of larvae, $\mathrm{SD}=35.0, \mathrm{~N}=36$ ) (Fig. 3). Substantial numbers of larvae were eaten even when phytoplankton was present (Experiment VII, Fig. 3). Numerous larvae were found at the end of each experiment fully or partially digested, or incorporated into fecal pellets (Fig. 4). We also noticed many empty larval shells.

Adult shell length was a poor predictor of larval consumption (Fig. $3, \mathrm{r}^{2}=0.075, \mathrm{~F}$ test for non-zero slope $=2.75 ; \mathrm{df}=1,34 ; \mathrm{p}=0.11$ ) (Data from Expt VII were excluded from this analysis since phytoplankton were present during feeding).

Larvae of Crepidula fornicata were also readily ingested by adult oysters (data not shown). For adults of C. gigas feeding on pre-competent larvae (approximately $515 \mu \mathrm{m}$ shell length), 6 of the 8 individuals tested removed at least $98 \%$ of larvae during the $6 \mathrm{~h}$ exposures, making it impossible to accurately estimate filtration rates. Adults of $O$. edulis consumed (Mean \pm SD) $68.7 \pm 24.2 \%$ (10 replicates) of precompetent larvae in $5.5 \mathrm{~h}$ in one experiment [mean larval shell length $\pm \mathrm{SD}(\mathrm{N})=539.6 \pm$ $42.4 \mu \mathrm{m}(13)$ ], and $89.5 \pm 9.9 \%$ (10 replicates) of precompetent larvae in $7 \mathrm{~h}$ in a second experiment [mean larval shell length $\pm \mathrm{SD}(\mathrm{N})=457.4 \pm 18.8 \mu \mathrm{m}(12)]$.

Fig. 3. Influence of adult shell length on rates of larval consumption by $C$. fornicata in 5-6 h experiments at $23^{\circ} \mathrm{C}$. Mean larval shell lengths \pm SD (N) were as follows: Exp I: $488.5 \pm 24.1 \mu \mathrm{m}(14)$;

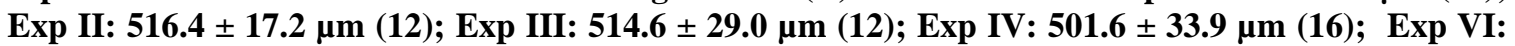
$512.3 \pm 35.2 \mu \mathrm{m}$ (26). Mean consumption for all data combined: $48.5 \%$ of larvae eaten \pm 32.5 (44).

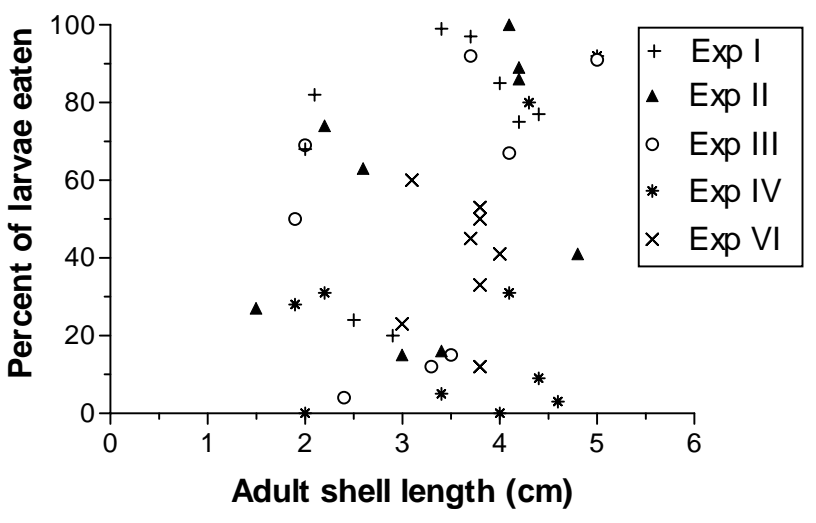


Fig. 4. Larvae of $C$. fornicata embedded in fecal strings produced by adults of their own species. The larvae were approximately $500 \mu \mathrm{m}$ in shell length.

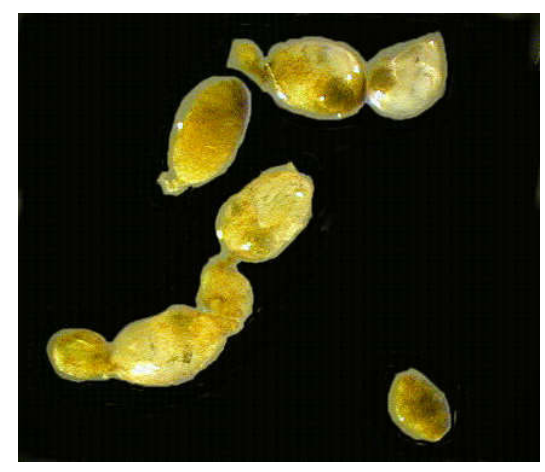

3.4. Comparison of filtration rates by adult slippershells and bivalves on phytoplankton and precompetent larvae

Filtration rates by adult $C$. fornicata feeding on their own larvae were poorly predicted from filtration rates of the same individuals feeding on phytoplankton (Fig. 5a); i.e., filtration rates based on disappearance of phytoplankton were significantly different from those based on rates of disappearance of larvae in the absence of phytoplankton (paired t-test, two-tailed $\mathrm{t}=3.71, \mathrm{df}=25, \mathrm{p}=0.001$ ). In particular, nearly $70 \%$ of the adult $C$. fornicata tested ingested precompetent larvae more slowly than predicted from the rates at which they consumed phytoplankton (Fig. 5a). Two of the individuals (indicated by rectangles around data points in Fig. 5a) ate at least $98 \%$ of larvae during the $6 \mathrm{~h}$ feeding period, so that filtration rates based on larval disappearance may have been underestimated for those 2 individuals. Filtration rates on larvae were substantially lower than predicted from rates of phytoplankton consumption when larvae and phytoplankton were present simultaneously (Exp VI, Fig. 5b).

In marked contrast, adults of the oyster Ostrea edulis generally consumed larvae at a rate considerably faster than that predicted (paired t-test, two-tailed $t=3.93, \mathrm{df}=9, \mathrm{p}=0.0035$ ) from the rates at which they consumed phytoplankton (Fig. 5c). As noted earlier, similar comparisons could not be made for the oyster C. gigas, because nearly all individuals consumed more than $98 \%$ of larvae during the $6 \mathrm{~h}$ study. 
Fig. 5. Degree to which filtration rates of adults on larvae were predicted by their filtration rates on phytoplankton. a) Adults of $C$. fornicata first fed on phytoplankton for 1-3 $\mathrm{h}$ and the same adults were then allowed to feed on larvae in filtered seawater for 5-6 h. Mean larval shell lengths are reported in the caption to Figure 2. b) Adults of $C$. fornicata were allowed to feed on larvae and phytoplankton simultaneously. Mean larval shell length $=512.3 \pm 35.2 \mu \mathrm{m}$ (26). Rectangles around data points indicate that adults ate at least $98 \%$ of larvae during the $6 \mathrm{~h}$ feeding period. c) Adults of the oyster Ostrea edulis were first allowed to feed on phytoplankton for 1-3 h, and then the same individuals were allowed to feed on larvae for $7 \mathrm{~h}$. Adult oysters ranged from 6.3 to $7.6 \mathrm{~cm}$ long. Mean larval shell length \pm SD (N) was $457.4 \pm 18.77 \mu \mathrm{m}(12)$.
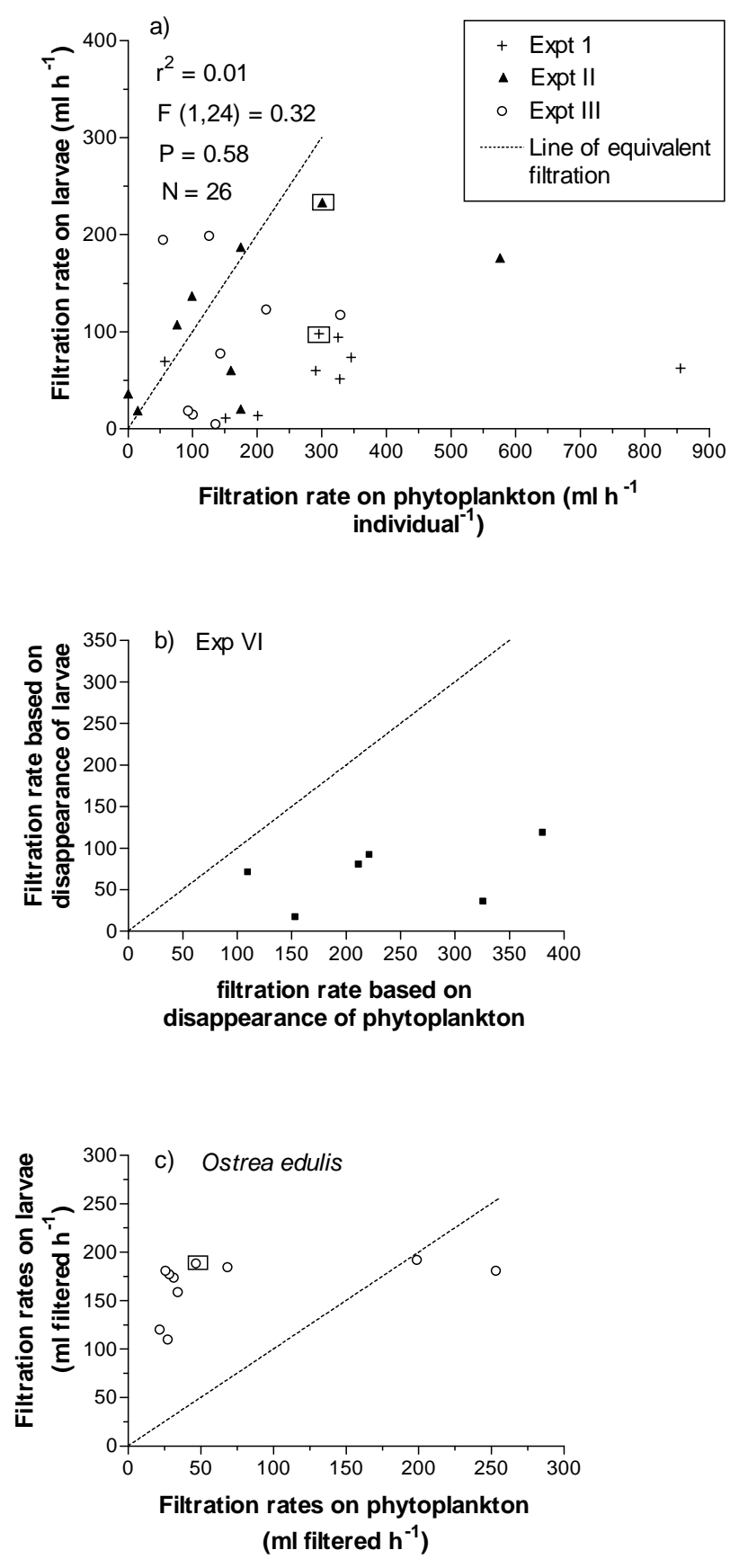


\subsection{Influence of larval size}

In 2 experiments (Experiments IV and VIII), larval size did not influence larval vulnerability significantly (Fig. 6a, Exp IV: Mean number eaten $=16.2 \%$ of large larvae, $27.6 \%$ of small larvae, MannWhitney U-test, $\mathrm{U}=45.5, \mathrm{p}=0.74$; Fig. 6c, Exp VIII: Mean number eaten $=35.8$ large larvae, 35.9 small larvae; paired t-test $\mathrm{t}=0.046, \mathrm{df}=9, \mathrm{p}=0.96$, pairing was effective $\mathrm{p}=0.0002)$. In one experiment (Exp VII), however, adults of $C$. fornicata consumed significantly more large larvae than small larvae (Fig. 6b; Mean number eaten $=20.2$ large larvae, 14.7 small larvae; paired t-test $t=5.37, \mathrm{df}=5, \mathrm{p}=0.003$, pairing was effective $\mathrm{p}=0.0012$ ).

Fig. 6. The influence of larval shell size on consumption of larvae by adults of $C$. fornicata. Different adults were used in each experiment, and allowed to graze on larvae for 5-6 $\mathrm{h}$ in the absence of phytoplankton. Mean larval shell lengths of small larvae \pm SD (N) were as follows: Exp IV: $501.6 \pm$

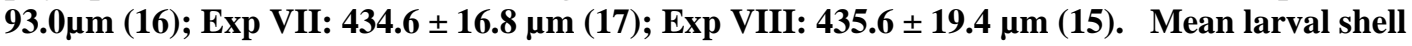
lengths of large larvae \pm SD (N) were as follows: Exp IV: 857.9 $\pm 33.9 \mu m$ (17); Exp VII: $622.5 \pm 35.26$ $\mu \mathrm{m}$ (20); Exp VIII: $753.9 \pm 37.6 \mu \mathrm{m}$ (16).
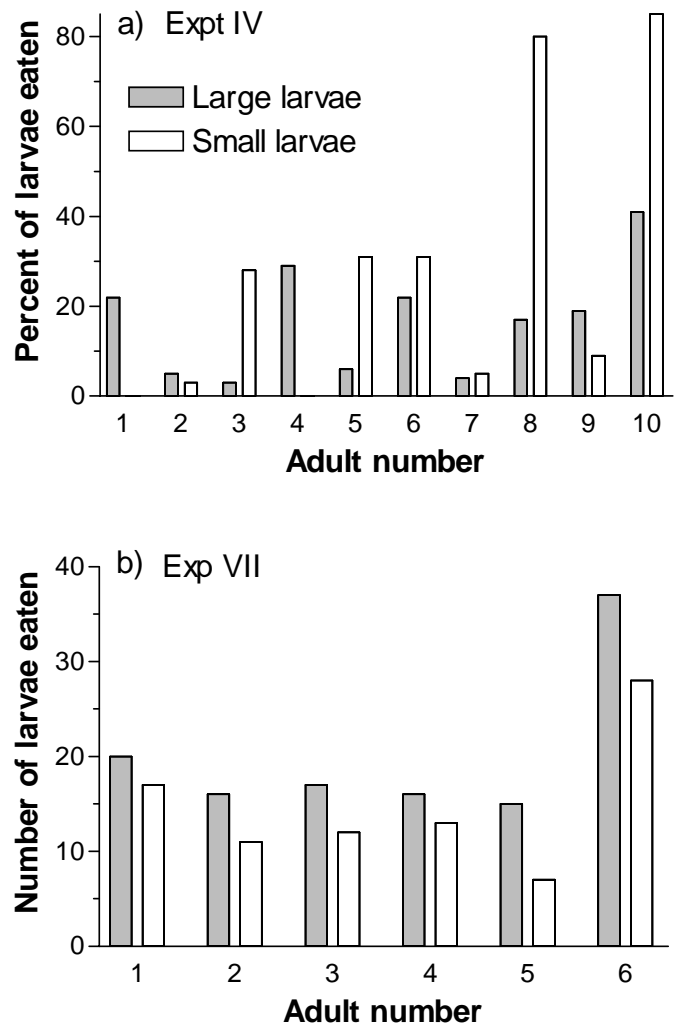

c) Exp VIII

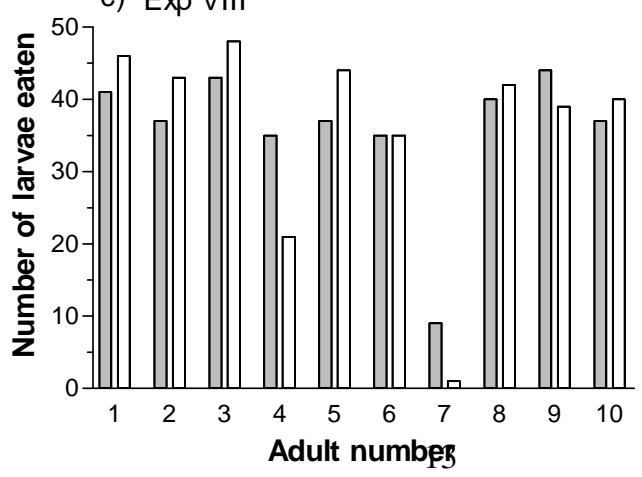




\subsection{Influence of phytoplankton}

In both experiments, adults of $C$. fornicata ate, on average, significantly fewer larvae $(p<0.05)$ when phytoplankton were present than they did in filtered seawater, although predation on larvae was still substantial in the presence of phytoplankton (Fig. 7).

Fig. 7. The influence of phytoplankton on consumption of larvae by adults of $C$. fornicata. Adults were allowed to feed for $4 \mathrm{~h}(\operatorname{Exp} \mathrm{IX})$ or $5 \mathrm{~h}(\operatorname{Exp} \mathrm{X})$ on larvae either in filtered seawater ("No food") or at a phytoplankton concentration of approximately $18 \times 10^{4}$ cells $\mathrm{mL}^{-1}$ ("Food"). Mean larval shell lengths \pm SD (N) were 596.2 $\pm 37.7 \mu \mathrm{m}(29)$ in Exp IX and 525.1 $\pm 38.6 \mu \mathrm{m}(24)$ in Exp X. Effects of food were analyzed by Mann-Whitney $U$ test in $\operatorname{Exp} X$ because variances were not homogeneous. Horizontal dotted lines represent means.

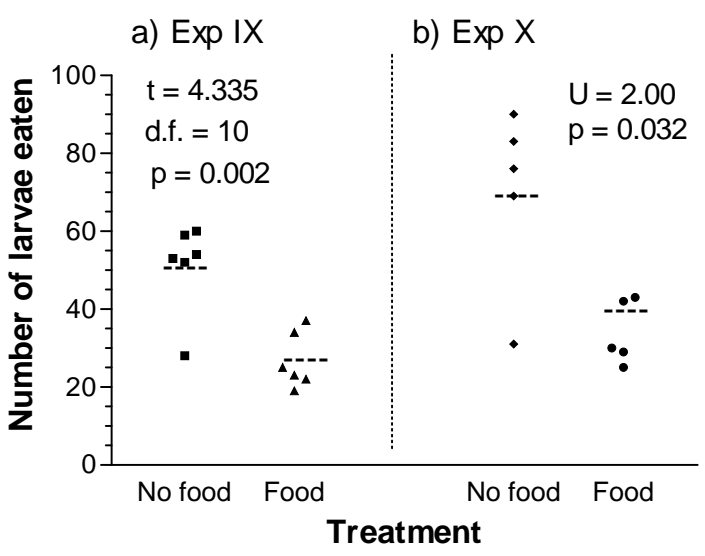




\subsection{Fate of competent larvae}

Despite substantial ingestion of larvae by adults of $C$. fornicata, many larvae managed to metamorphose on the shells of adults or on the sides of the plastic jars during the $6 \mathrm{~h}$ experiments (Fig. 8). In Exp V, for example ( $\mathrm{N}=4$ adults), an average of $50 \%$ of larvae were eaten ( $\mathrm{SD}=11.26, \mathrm{~N}=4$ ), while $31 \%$ metamorphosed ( $\mathrm{SD}=5.7, \mathrm{~N}=4$ ) (Fig. 8b). In that experiment, more than $90 \%$ of the larvae were competent to metamorphose (mean $=91.3 \%$ competent, $\mathrm{SD}=4.0 \%, \mathrm{~N}=3$ ).

Substantial numbers of competent larvae also managed to metamorphose in the presence of adult oysters (Ostrea edulis), despite their very high filtration rates (Fig. 9). In one experiment (Fig. 9a), an average of $47.6 \%$ ( $S D=10.1, \mathrm{~N}=10$ replicates) of larvae were consumed during the $6.5 \mathrm{~h}$ test period, and yet an average of $43.4 \%(\mathrm{SD}=9.0)$ of individuals metamorphosed. In the second experiment (Fig 9b), an average of $64.8 \%$ ( $\mathrm{SD}=25.0, \mathrm{~N}=10$ replicates) of larvae were consumed during the $6.5 \mathrm{~h}$ test period, and yet an average of $9.9 \%(\mathrm{SD}=5.3)$ of individuals managed to metamorphose.

Fig. 8. The fate of competent larvae in the presence of adults of $C$. fornicata. Adults were allowed to feed on larvae for $6 \mathrm{~h}$ in the absence of phytoplankton. The mean percentage of larvae $( \pm$ SD) competent to metamorphose was $9.5 \pm 8.3 \%$ (3) for Exp IV; $91.3 \% \pm 4.0$ (3) in Exp V; and $46.8 \pm 9.4$ $\%$ (3) in Exp XI. Mean larval shell lengths \pm SD (N) were as follows: Exp IV: $857.9 \pm 93.2 \mu \mathrm{m}$ (17); Exp V: 976 \pm 17.2 (38); Exp XI: 817.6 \pm 29.0 (21).

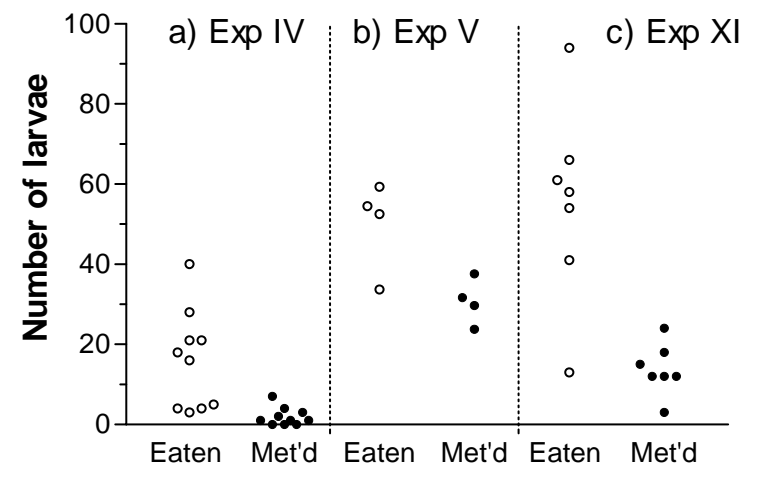


Fig. 9. The fate of competent larvae in the presence of adults of Ostrea edulis. Adults were allowed to feed on larvae for $6 \mathrm{~h}$ in the absence of phytoplankton. The mean percentage of larvae competent to metamorphose was $91.3 \pm 4.0 \%$ (3) in (a) and $46.8 \pm 9.4 \%$ (3) in (b). Mean larval shell lengths \pm SD (N) were 821.9 $\pm 73.2 \mu \mathrm{m}(13)$ in (a) and $976 \pm 17.2 \mu \mathrm{m}$ (38) in (b). Adult shell lengths ranged from $7.0-7.6 \mathrm{~cm}$ in (a) and from $6.7-7.0 \mathrm{~cm}$ in (b).

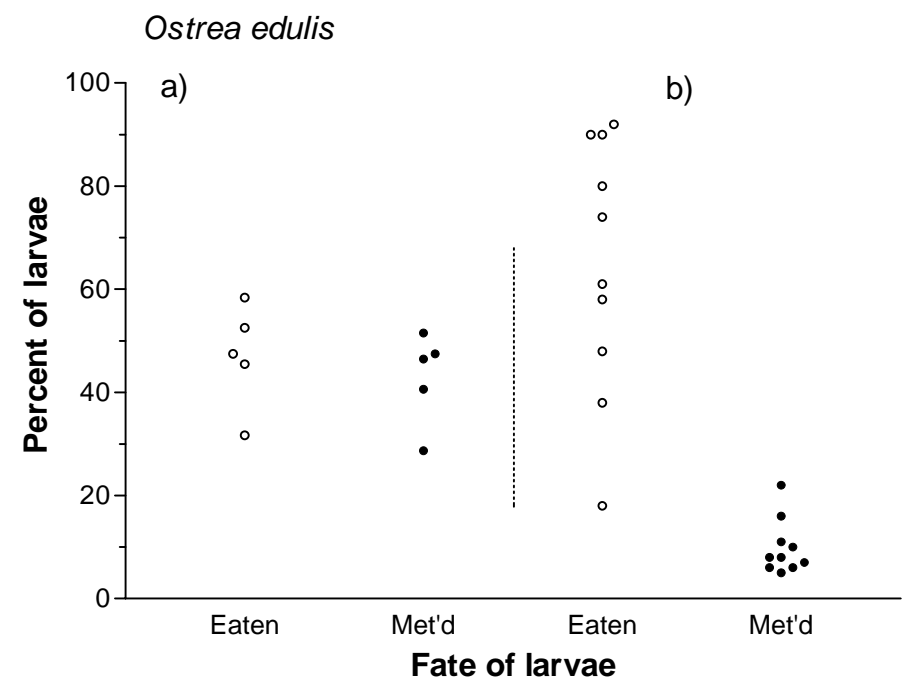

\subsection{Direct observations on ingestion of precompetent larvae by adult Crepidula}

In Observation A, 10 larvae were forcefully ejected when individually pipetted into the incurrent stream at the left side of one adult $(2.9 \mathrm{~cm}$ shell). In 5 cases larvae swam or were drawn into the adult mantle cavity and then leisurely swam out within about 15 seconds. In Observations B and C, no larvae were ingested when offered to the right of the midline but all larvae (15 and 12, respectively) were taken into the mantle cavity when gently pipetted just to the left of the midline, and none were rejected (adult shell lengths $1.2 \mathrm{~cm}$ and $2.3 \mathrm{~cm}$ respectively). In Observation D, in which 50 larvae were swimming freely in the dish at the start, 11 were drawn into the mantle cavity on the left side of the adult $(2.1 \mathrm{~cm}$ shell) within the first 10 minutes of observation, and none emerged; fecal pellets containing larvae were noticed about 1.25 h later.

\section{Discussion}

The filtration rates that we recorded for adults of $C$. fornicata feeding on phytoplankton in this study, averaging about $225 \mathrm{~mL} \cdot \mathrm{h}^{-1} \cdot$ individual $^{-1}$, agree well with those reported in previous studies conducted at comparable temperatures (Newell and Kofoed, 1977a, b; Lesser et al., 1992). Our observation that adults of this species feed erratically also matches prior findings (Newell and Kofoed, 1977a). However, in our study the same adults usually ingested their own larvae at much slower rates than predicted from the rates at which they cleared water of phytoplankton. These slower rates may in part reflect an inability or 
reluctance of adults to ingest particles of such large size; some larvae of about 500-600 $\mu$ m shell length were forcefully ejected by adults in some trials in which larvae were pipetted directly into the intake current. However, most of the larvae that we observed being entrained into adult feeding currents were ingested, and later appeared in feces, and adults were capable of ingesting larvae that were larger by at least $200 \mu \mathrm{m}$. Thus, lower than predicted rates of larviphagy by C. fornicata more likely reflect larval behavior-deliberate or not--reducing the likelihood of entrainment into the adult feeding current, as suggested previously from studies with solitary ascidians feeding on natural zooplankton assemblages (Bingham and Walters, 1989). Copepods, for example, can detect the fluid deformations caused by filtering bivalves from a distance, and escape capture by jumping (Green et al., 2003). The behavioral responses of $C$. fornicata larvae to gentle suction have not yet been documented. Normal swimming activity might also reduce the likelihood of consumption by adults, to the extent that larvae can maintain themselves near the surface and away from the incurrent stream of adults despite water circulation within the test containers.

Larval size did not have a major impact on predation rates by adults of $C$. fornicata. This result is in striking contrast to results of adult oysters (Crassostrea virginica) feeding on inert beads of different sizes; in those studies, ingestion rates declined linearly and dramatically as particle size was increased from 10 to $410 \mu \mathrm{m}$ (Tamburri and Zimmer-Faust, 1996). Indeed, in one of our experiments predation rates were higher on larger larvae; increased larval size seems to offer no protection from predation by C. fornicata.

It is difficult to estimate predation rates on larvae in the field from laboratory experiments. In the present study, rates estimated in the laboratory using filtered seawater were artificially high. This may also be true for past studies (e.g., Timko, 1979; Young, 1990) in which experiments were conducted in the absence of phytoplankton. On the other hand, Tamburri and Zimmer-Faust (1996) found that oysters ingested their own larvae faster (by about 14\%) in the presence of phytoplankton, and that the presence of phytoplankton did not significantly alter predation by oysters upon barnacle cyprids or polychaete trochophores. In our study, it seems likely that predation on larvae was reduced in the presence of phytoplankton simply because the adult gut filled with other foods when other foods were present (Johnson and Shanks, 2003); there is no evidence from our data that adults of C. fornicata are preferentially herbivorous, although that possibility is not ruled out by our experiments to date. Adults ingested their own larvae even in the presence of phytoplankton, and substantial numbers of larvae were consumed even at high phytoplankton concentrations. The adults seem to be omnivorous, ingesting whatever they can trap.

The magnitude of predation by adults on their own larvae in the field will also vary with current speed, degree of turbulence, adult density (André et al., 1993), and perhaps the swimming behavior of the larvae. André et al. (1993) determined that cockle larvae (Cerastoderma edule) passing through a bed of adults at 380 individuals $\mathrm{m}^{-2}$ had an average survival time of only $60 \mathrm{~s}$. With adult densities of Crepidula fornicata reaching many thousands per $\mathrm{m}^{2}$ (Ehrhold et al., 1998), the impact of adults on the survival of both precompetent larvae at release and competent individuals during substrate selection is potentially enormous. Predation on Crepidula larvae passing through dense beds of oysters must also be substantial: in the present study, the larvae of $C$. fornicata were ingested by the oyster Ostrea edulis at rates higher than those predicted from rates at which phytoplankton were ingested. The larvae were also readily consumed by adults of the oyster Crassostrea gigas. Even so, our data suggest that many larvae will successfully recruit to adult populations even at high adult densities, in part because larvae are likely to be entrained only within a narrow region around the shell of each adult, as reported for ascidians (Young, 1990). On the other hand, adults of $C$. fornicata usually aggregate in stacks, so that larvae will potentially encounter a series of these horizontally oriented water currents as they are first released into the water and as they later descend to explore substrata. It is difficult to anticipate the combined effects of entire stacks of individuals on the fate of competent larvae in the field, particularly as different stacks are oriented in different directions. Also, in previous studies of predation upon larvae by suspension-feeders, the predators (ascidians and bivalves-e.g., Young, 1990; André et al., 1993; Tamburri and Zimmer-Faust, 1996) have generated feeding currents that moved downwards, into siphons that were oriented vertically. In contrast, the incurrent stream for adults of $C$. fornicata is oriented horizontally. The effect of differences in adult orientation on larval vulnerability to capture awaits investigation, through both flume and field studies.

In our experiments, predation on Crepidula larvae by adult oysters was even greater than that by adult Crepidula; however, the oysters used in this study were much larger than the adult Crepidula used, reflecting natural adult size differences among species. Additional studies will be required to determine the extent to which these differences in consumption rates are explained by factors other than differences in adult size. 
Crepidula fornicata is generally thought of and treated as an herbivore (e.g., Newell and Kofoed, 1977a, b; Pechenik and Eyster, 1989; Lesser et al., 1992). Nevertheless, we show here that the adults can ingest larvae of at least $800 \mu \mathrm{m}$ in shell length; thus zooplankton must form a substantial part of the normal diet, an inference supported by recent studies of $\mathrm{C}^{13} / \mathrm{N}^{15}$ ratios (Riera, 2002). Similarly, adults of the blue mussel, Mytilus edulis, routinely ingest prey of about $500 \mu \mathrm{m}$, with the largest adults capable of ingesting zooplankton of at least several $\mathrm{mm}$ in length (Lehane and Davenport, 2002). The contribution of zooplankton in meeting the energetic and nutritional needs of $C$. fornicata and other suspension-feeding animals remains to be explored.

\section{Acknowledgements}

We are grateful to the directors and staff of the laboratories in Dinard and Argenton for providing facilities and equipment in support of this research. We thank Gordon Hendler and 2 anonymous reviewers for their thoughtful suggestions on a draft of the manuscript.

\section{References}

Bayne, B.L., 1965. Growth and the delay of metamorphosis of the larvae of Mytilus edulis (L.). Ophelia 2, 147.

Bayne, B.L. 1976. Marine Mussels, Their Ecology and Physiology. Cambridge University Press, NY.

Bingham, B.L., Walters L.J., 1989. Solitary ascidians as predators of invertebrate larvae, evidence from gut analyses and plankton samples. J. Exp. Mar. Biol. Ecol. 131, 147-159.

Blanchard, M., 1997. Spread of the slipper limpet Crepidula fornicata (L. 1758) in Europe. Current state and consequences. Sci. Mar. 61 (Suppl 2), 109-118.

Blanchard, M., Ehrhold, A., 1999. Cartographie et evaluation du stock de la crépidule (Crepidula fornicata) en baie du Mont Saint Michel. Haliotis 28, 11-20.

Burke, R.D., 1986. Pheromones and the gregarious settlement of marine invertebrate larvae. Bull. Mar. Sci. 39, 323-331.

Chaparro, O.R., Thompson, R.J., Ward, J.E., 1993. In vivo observations of larval brooding in the Chilean oyster, Ostrea chilensis Philippi, 1845. Biol. Bull. 185, 365-372.

Chipperfield, P.N.J., 1951. The breeding of Crepidula fornicata (L.) in the River Blackwater, Essex. J. Mar. Biol. Ass. U.K. 30, 49-71.

Coe, W.R., 1936. Sexual phases in Crepidula. J. Exp. Zool. 72, 455-477.

Collin, R., 1995. Sex, size, and position, a test of models predicting size at sex change in the protandrous gastropod Crepidula fornicata. Amer. Bat. 146, 815-831.

Coon, S.L., Bonar, D.B., 1986. Norepinephrine and dopamine content of larvae and spat of the Pacific oyster, Crassostrea gigas. Biol. Bull. 171, 632-639.

Cowden, C., Young, C.M., Chia, F.S., 1984. Differential predation on marine invertebrate larvae by two benthic predators. Mar. Ecol. Progr. Ser. 14, 145-301.

Davis, H.C., Ansell, A.D., 1962. Survival and growth of larvae of the European oyster, O. edulis, at lowered salinities. Biol. Bull. 122, 33-39.

Davis, H.C., Calabrese, A., 1964. Combined effects of temperature and salinity on development of eggs and growth of larvae of M. mercenaria and C. virginica. Fish. Bull. 63, 643-655.

Declerck, C.H., 1995. The evolution of suspension feeding in gastropods. Biol. Rev. 70, 549-569.

Ehrhold, A., Blanchrd, M., Aufrfret, J.-P., Garalan, T., 1998. The role of Crepidula proliferation in the modification of the sedimentary tidal environment in Mont-Saint-Michel Bay (The Channel, France). C.R. Acad. Sci. Paris, Earth and Planet. Sci. 327, 583-588.

Gaffney, P.M., McGee, B., 1992. Multiple paternity in Crepidula fornicata (Linnaeus). The Veliger 35, 1215.

Green, S., Visser A.W., Titelman, J., Kiørboe., 2003. Escape responses of copepod nauplii in the flow field of the blue mussel, Mytilus edulis. Mar. Biol. 142, 727-733.

Hoagland, K.E., 1978. Protandry and the evolution of environmentally-mediated sex change: a study of the Mollusca. Malacologia 17: 365-391.

Jakobsen, H.H., 2001. Escape response of planktonic protists to fluid mechanical signals. Mar. Ecol. Progr. Ser. 214: 67-78. 
Johnson, K.B., Shanks, A.L., 2003. Low rates of predation on planktonic marine invertebrate larvae. Mar. Ecol. Progr. Ser. 248, 125-139.

Korringa, P., 1951. Crepidula fornicata as an oyster-pest. Cons. Int. Explor. Mer. Rapp. et Proc.-Verb 128, 55-59.

Lehane, C., Davenport, J., 2002. Ingestion of mesozooplankton by three species of bivalves; Mytilus edulis, Cerastoderma edule and Aequipecten opercularis. J. Mar. Biol. Assoc. U.K. 82, 615-619.

Lesser, M.P., Shumway, S.E., Cucci, T., Smith, J., 1992. Impact of fouling organisms on mussel rope culture: interspecific competition for food among suspension-feeding invertebrates. J. Exp. Mar. Biol. Ecol. 165, 91-102.

Marin, V., Huntley, M.E., Frost, B., 1986. Measuring feeding rates of pelagic herbivores, analysis of experimental design and methods. Mar. Biol. 93, 49-58.

McGee, B.L., Targett, N.M., 1989. Larval habitat selection in Crepidula (L.) and its effect on adult distribution patterns. J. Exp. Mar. Biol. Ecol. 131, 195-214.

Mileikovsky, S.A., 1974. On predation of pelagic larvae and early juveniles of marine bottom invertebrates by adult benthic invertebrates and their passing alive through their predators. Mar. Biol. 26, 303-311.

De Montaudouin, X. , Audemard, C., Labourg, P.-J., 1999. Does the slipper limpet (Crepidula fornicata, L.) impair oyster growth and zoobenthos biodiversity? A revisited hypothesis. J. Exp. Mar. Biol. Eco. 235, 105-124.

Morgan, S.G., 1992. Predation by plankton and benthic invertebrates on larvae of estuarine crabs. J. Exp. Mar. Biol. Ecol. 163, 91-110.

Morgan, S.G., 1995. Life and death in the plankton: larval mortality and adaptation. In: McEdward, L. (Eds.), Ecology of Marine Invertebrate Larvae. CRC Press, New York, pp. 279-321.

Newell, R.C., Kofoed, L.H., 1977a. Adjustment of the components of energy balance in the gastropod Crepidula fornicata in response to thermal acclimation. Mar. Biol. 44, 275-286.

Newell, R.C., Kofoed, L.H., 1977b. The energetics of suspension-feeding in the gastropod Crepidula fornicata L. J. Mar. Biol. Assoc. U.K. 57, 161-180.

Pawlik, J.R., 1990. Natural and artificial induction of metamorphosis of Phragmatopoma lapidos californica (Polychaeta: Sabellariidae) with a critical look at the effects of bioactive compounds on marine invertebrate larvae. Bull. Mar. Sci 46, 512-536.

Pechenik, J.A., 1980. Growth and energy balance during the larval lives of three prosobranch gastropods. J. Exp. Mar. Biol. Ecol. 44, 1-28.

Pechenik, J.A., 1984. The relationship between temperature, growth rate, and duration of planktonic life for larvae of the gastropod Crepidula fornicata (L.). J. Exp. Mar. Biol. Ecol. 74, 241-257.

Pechenik, J.A., 1999. On the advantages and disadvantages of larval stages in benthic marine invertebrate life cycles. Mar. Ecol. Progr. Ser. 177, 269-297.

Pechenik, J.A., Eyster, L.S., 1989. Influence of delayed metamorphosis on the growth and metabolism of young Crepidula fornicata (Gastropoda) juveniles. Biol. Bull. 176, 14-24.

Pechenik, J.A., Gee, C.C., 1993. Onset of metamorphic competence in larvae of the gastropod Crepidula fornicata (L.), judged by a natural and an artificial cue. J. Exp. Mar. Biol. Ecol. 167, 59-72.

Pechenik, J.A., Heyman, W.D., 1987. Using KCl to determine size at competence for larvae of the marine gastropod Crepidula fornicata (L.). J. Exp. Mar. Biol. Ecol. 112, 27-38.

Pechenik, J.A., Eyster, L.S., Widdows, J., Bayne, B.L., 1990. The influence of food concentratin and temperature on growth and morphological differentiation of blue mussel Mytilus edulis L. larvae. J. Exp. Mar. Biol. Ecol. 136, 47-64.

Pechenik, J.A., Hilbish, T.J., Eyster, L.S., Marshall, D., 1996. Relationship between larval and juvenile growth rates in two marine gastropods, Crepidula plana and C. fornicata. Mar. Biol. 125, 119-127.

Pechenik, J.A., Li, W., Cochrane, D.E. 2002. Timing is everything: The effects of putative dopamine antagonists on metamorphosis vary with larval age and experimental duration in the prosobranch gastropod Crepidula fornicata. Biol. Bull. 202, 137-147.

Pires, A., Guilbault, T.R., Mitten, J.V., Skiendzielewiski, J.A., 2000. Catecholamines in larvae and juveniles of the prosobranch gastropod, Crepidula fornicata. Comp. Biochem. Physiol. C 127, 37-47.

Riera, P., Stal, L.J., Nieuwenhuize, J., 2002. $\delta^{13} \mathrm{C}$ versus $\delta^{15} \mathrm{~N}$ of co-occurring mollusks within a community dominated by Crassostrea gigas and Crepidula fornicata (Oosterschelde, The Netherlands). Mar. Ecol. Progr. Ser. 240, 291-295.

Rumrill, S.S., 1990. Natural mortality of marine invertebrate larvae. Ophelia 32, 163-198. 
Sauriau, P.-G., Pichocki-Seyfried, C., Walker, P., de Montaudouin, X, Palud, C., Héral, M., 1998. Crepidula fornicata L. (mollusque, gastéropode) en baie de Marennes-Oléron: cartographie des fonds par sonar à balayage latéral et estimation du stock. Oceanolog. Acta 21, 353-362.

Sjøtun, K., 1997. A new observation of Crepidula fornicata (Prosobranchia, Calyptraeidae) in Western Norway. Sarsia 82, 275-276,

Tamburri, M.N., Zimmer-Faust, R.K., 1996. Suspension-feeding: basic mechanisms controlling recognition and ingestion of larvae. Limnol. Oceanogr. 41, 1188-1197.

Thieltges, D.W., Strasser, M., Reise, K., 2003. The American slipper limpet Crepidula fornicata (L.) in the northern Wadden Sea 70 years after its introduction. Helgoland. Mar. Res. 57, 27-33.

Thorson, G., 1950. Reproductive and larval ecology of marine bottom invertebrates. Biol. Rev. 25, 1-45.

Timko, P., 1979. Larviphagy and oophagy in benthic invertebrates: a demonstration for Dendraster excenticus (Echinoidea). In: Stancyk, S.E. (Ed), Reproductive Ecology of Marine Invertebrates. University of South Carolina Press, Columbia, pp. 91-98.

Titelman, J., 2001. Swimming and escape behavior of copepod nauplii: implications for predator-prey interactions among copepods. Mar. Ecol. Progr. Ser. 213, 201-213.

Walne, P.R., 1956. The biology and distribution of the slipper limpet Crepidula fornicata in Essex Rivers, with notes on the distribution of the larger epi-benthic invertebrates. Fish. Invest. Ser. II 20, 1-50.

Willemsen, J., 1954. Quantities of water pumped by mussels (Mytilus edulis) and cockles (Cardium edule). Arch. Néerland. Zool. 153-159.

Woodin, S.A., 1976. Adult-larval interactions in dense infaunal assemblages: patterns of abundance. J. Mar. Res. 34, 25-41.

Wright, W.G., 1988. Sex change in the Mollusca. TREE 3, 137-140.

Young, C.M., 1988. Ascidian cannibalism correlates with larval behavior and adult distribution. J. Exp. Mar. Biol. Ecol. 117, 9-26.

Young, C.M., 1990. Larval predation by epifauna on temperate reefs: scale, power and the scarcity of measurable effects. Austr. J. Ecol. 15, 413-426.

Young, C.M., Chia, F.S., 1987. Abundance and distribution of pelagic larvae as influenced by predation, behavior, and hydrographic factors. In: Giese, A.C., Pearse, J.S., Pearse, V.B. (Eds.), Reproduction of Marine Invertebrates. Blackwell Scientific, Palo Alto, pp. 385-463. 